\title{
Perlindungan Hukum Kepentingan Para Pihak dalam Transaksi Online
}

\author{
Ni Luh Diah Febriyani Teja Santi ${ }^{1}$
}

1 Program Studi Magister (S2) Kenotariatan Fakultas Hukum Universitas Udayana, E-mail:diahtejasanti@gmail.com

\begin{abstract}
Info Artikel
Masuk : 17 Juli 2019

Diterima : 14 Agustus 2019

Terbit : 30 Desember 2019

Keywords :

Legal protection; Traditional

Knowledge; Copyrights

Kata kunci:

Pemulihan hak; Notaris;

Putusan Pengadilan

Corresponding Author:

Gde Dianta Yudi Pratama,

E-mail:

diahtejasanti@gmail.com

DOI :

10.24843/AC.2019.v04.i03.p13
\end{abstract}

\begin{abstract}
E-Commerce is now a new business model that is increasingly loved by the people of Indonesia. Internet support that makes business patterns loved for reasons of convenience offered. The change in the way transactions in the business world into the virtual world has given birth to various new legal problems. The action is not safe because it still has some weaknesses so this research tries to formulate and answer several problems, namely how is the mechanism and arrangement of transactions using online media and how is the protection of the interests of the parties in online transactions. The method used in this study is a normative method supported by a statutory approach and a conceptual and analytical approach. The results of this study indicate that the mechanism of buying and selling agreements using online through an intermediary or business actor where the prospective buyer must first enter the business actor's website and then have been accepted as a member of the intermediary or business actor, the next step is allowed to see the catalog of goods and then make a transaction. And legal protection for the parties including: Legal protection for merchants emphasizes payment, the merchant requires customers to make payments in full, then confirms payment, and the next step is to deliver goods that have been purchased, legal protection for customers is under warranty i.e. return or exchange of goods if the goods received are not like what was purchased and Privacy. Legal protection in online transactions is not only given by one legal aspect, but by a legal system that is able to provide simultaneous and comprehensive protection.

\begin{tabular}{l}
\hline Abstrak \\
\hline E-Commerce atau yang disebut transaksi online dewasa ini \\
menjadi model bisnis baru yang semakin digandrungi oleh \\
masyarakat Indonesia. Dukungan internet yang membuat pola \\
bisnis digandrungi karena alasan kemudahan yang ditawarkan. \\
Adanya perubahan cara transaksi dalam dunia bisnis ke dalam \\
dunia virtual telah melahirkan berbagai masalah hukum baru. \\
Tindakan tersebut tidaklah aman sebab masih memiliki beberapa \\
kelemahan sehingga penelitian ini mencoba untuk merumuskan \\
dan menjawab beberapa permasalahan yaitu Bagaimanakah \\
mekanisme dan pengaturan transaksi dengan menggunakan \\
media online dan Bagaimanakah perlindungan terhadap \\
kepentingan para pihak dalam transaksi online. Metode yang \\
digunakan dalam penelitian ini adalah metode normatif dengan \\
didukung oleh pendekatan perundang-undangan serta \\
pendekatan konseptual dan analisis. Hasil penelitian ini
\end{tabular}
\end{abstract}


menunjukkan bahwa perjanjian jual beli dengan menggunakan online melalui perantara atau pelaku usaha dimana calon pembeli, pertama harus memasuki website pelaku usaha dan kemudian telah diterima menjadi anggota perantara atau pelaku usaha, langkah selanjutnya diperkenankan melihat katalog barang serta kemudian melakukan transaksi dan perlindungan hukum untuk para pihak diantaranya: Perlindungan hukum terhadap merchant menekankan pada pembayaran, merchant mewajibkan customer untuk melaksanakan pembayaran secara lunas, selanjutnya dilakukan konfirmasi pembayaran, dan tahap berikutnya adalah melakukan pengiriman barang-barang yang telah dibeli, Perlindungan hukum untuk customer berada pada garansi yaitu pengembalian atau penukaran barang apabila barang yang diterima tidak seperti apa yang dibeli dan Privacy.Perlindungan hukum dalam traansaksi online tidak hanya diberikan oleh satu aspek hukum saja melainkan oleh suatu sistem hukum yang mampu memberikan perlindungan yang simultan dan komprehensif.

\section{Pendahuluan}

Pada jaman dahulu perdagangan dilakukan dengan sistem barter antara para pihak yang bertemu langsung untuk melakukan kesepakatan mengenai sesuatu yang akan dipertukarkan tanpa adanya perjanjian. Sistem perdagangan mengalami perubahan dengan perkembangan teknologi yaitu dengan ditemukan internet sebuah teknologi yang memungkinkan kita melakukan suatu pertukaran informasi dengan siapapun dan dimana pun orang tersebut berada tanpa adanya batasan ruang dan waktu. Dengan perdagangan lewat internet ini berkembang pula sistem bisnis virtual, seperti virtual store dan virtual company di mana pelaku bisnis menjalankan bisnis dan perdagangannya melalui media internet dan tidak lagi mengandalkan bisnis perusahaan konvensional yang nyata. ${ }^{1}$ Kehadiran internet sebagai sebuah revolusi teknologi informasi membawa dampak besar bagi peradaban manusia. ${ }^{2}$ Teknologi yang diciptakan berkembang seiring dengan kebutuhan manusia untuk memudahkan hidup dari yang sebelumnya. Teknologi informasi dapat dimanfaatkan sebagai sarana untuk saling berkomunikasi, dimanfaatkan untuk penyebaran dan pencarian data, kegiatan belajar mengajar, memberi pelayanan, dan untuk melakukan transaksi bisnis. ${ }^{3}$

Bidang teknologi komunikasi atau informasi menyebabkan bergesernya konsep pasar tradisional menjadi "tele marketing" (pasar jarak jauh dengan menggunakan media internet)" Transaksi ekonomi kini telah di padukan dengan teknologi internet yang kemudian sering di sebut e-commerce. E-commerce atau transaksi elektronik

1 Tetanoe, Bernada, 2017, Upaya Perlindungan Hukum Pada Konsumen Dalam Transaksi ECommerce Untuk Mendukung Pertumbuhan Ekonomi Digital Di Indonesia Journal Jurnal Hukum dan Peradilan, Vol. 6 Nomor 1, Fakultas Hukum Universitas Pelita Harapan, hlm.2

2 Ni Ketut Dewi Megawati, 2016, Perspektif Undang-Undang No. 1 Tahun 2011 Tentang Perumahan dan Kawasan Pemukiman Terhadap Perlindungan Hak Konsumen Dalam Jual Beli Perumahan, Journal Magister Hukum Udayana, Vol. 5 No. 1, Denpasar, Program Studi Magister Ilmu Hukum Pasca Sarjana Universitas udayana,hlm. 13

${ }^{3}$ Abdul Halim Barkatullah, 2009, Perlindungan Hukum bagi konsumen dalam Transaksi E-commerce, Yogyakarta : Pascasarjana FH UII Press, hlm 1 
sebagaimana diatur dalam UU No. 19 Tahun 2016 tentang perubahan atas UU Nomor 11 Tahun 2008 tentang Informasi dan Transaksi Elektronik pada Pasal 1 ayat 2. Dengan memanfaatkan jaringan komunikasi internet baik dengan kemampuan cakupan komunikasi lokal, regional maupun global. Berlainan dengan di dunia nyata, dalam dunia maya inilah (cyber world), subjek hukum pada waktu yang bersamaan (real time) karena memiliki aksesbilitas yang sedemikian rupa. Konsep pasar tradisional kini telah mengalami perubahan yang sangat revolusioner dalam cara dan bentuknya tanpa transaksi atau hubungan hukum jual belinya akan kehilangan keabsahan, cacat hukum atau bahkan batal demi hukum.

Fase perkembangan dunia seperti ini, ditandai pula dengan bergesernya pengertian pasar menurut konsep tradisional, dimana penjual secara fisik bertemu dengan pembeli di dunia nyata, kini sudah mulai berkembang yaitu adanya transaksi online sebagai salah satu alternatif yang ditempuh oleh sebagian besar orang untuk menyelesaikan sebuah bisnis tanpa harus bertemu secara langsung (face to face) dan non-sign (tidak memakai tanda tangan asli). ${ }^{4}$ Model bisnis ini di katakan lebih praktis dan lebih mudah, tentu juga kondisi tersebut menyebabkan jarak bukan menjadi hambatan dalam dunia bisnis sehingga dapat dikatakan e-commerce menjadi penggerak ekonomi baru dalam bidang teknologi. ${ }^{5}$

Dalam transaksi elektronik perjanjian dilakukan secara elektronik dengan menggunakan komputer yang terhubung dengan jaringan internet yang kemudian disebut sebagai perjanjian elektronik atau kontrak elektronik. Model transaksi elektronik yang menggunakan perjanjian elektronik atau kontrak elektronik juga memuat beberapa unsur yang harus dipenuhi didalamnya. Unsur dalam perjanjian elektronik diatur dalam Pasal 48 ayat (3) Peraturan Pemerintah No. 82 Tahun 2012 Tentang Penyelenggaraaan Sistem dan Transaksi elektronik yang tujuannya jelas untuk memberikan kepastian hukum sebagai salah satu perlindungan hukum dalam transaksi elektronik.

Dewasa ini perkembangan electronic commerce menjadi semakin penting karena banyak aktivitas bisnis dapat dilakukan secara lebih banyak, cepat dan tentunya murah. Electronic commerce merupakan suatu fenomena baru yang yang memiliki aspek-aspek hukum yang tidak kalah pentingnya dibanding aspek-aspek ekonominya. Aspek aspek hukum dalam elctronic commerce adalah seperti barang bukti, kepercayaan dan tanggung jawab, pembayaran elektronik, privasi atau data personal, multi- lingualism dan multi-culturalism dan juga kebiasaan serta pajak. Teknologi informasi dan komunikasi saat ini sedang mengarah kepada konvergensi yang memudahkan kegiatan manusia sebagai pencipta, pengembang dan pengguna teknologi itu sendiri. Salah satunya dapat dilihat dari perkembangan media internet yang sangat pesat. Internet sebagai suatu media informasi dan komunikasi elektronik telah banyak dimanfaatkan untuk berbagai kegiatan, antara lain untuk menjelajah (browsing, surfing), mencari data dan berita, saling mengirim pesan melalui email, dan perdagangan. Kegiatan perdagangan dengan memanfaatkan media internet ini dikenal dengan istilah electronic commerce. Transaksi jual beli secara elektronik merupakan salah satu perwujudan ketentuan di atas. Pada transaksi jual beli secara elektronik ini,

\footnotetext{
${ }^{4}$ Iman Sjahputra, 2010, Perlindungan Konsumen dalam Transaksi Elektronik, Bandung : PT. Alumni, hlm, 23

${ }^{5}$ Ridyanti Dorotea Tobing, 2015, Aspek-Aspek Hukum Bisnis Pengertian, Asas, Teori dan Praktik, Palangka Raya, LaksBang Justitia, hlm. 224
} 
para pihak yang terkait didalamnya, melakukan hubungan hukum yang dituangkan melalui suatu bentuk perjanjian atau kontrak yang juga dilakukan secara elektronik.

Di samping nilai manfaat yang sangat tinggi, electronic commerce membawa masalah dan hambatan dalam penegakan hukum, sejumlah masalah dapat terjadi dengan sistem perdagangan seperti masalah keamanan data transaksi jual beli terhadap pihakpihak lain yang dapat menyadapnya, masalah pengawasan pajak, masalah pengawasan terhadap materi yang diperjualbelikan, masalah kejahatan elektronik dan masalah perlindungan hukum serta aspek-aspek hukum yang berjalan seiring dengan perkembangan teknologi di masyarakat. Perjanjian jual beli dengan menggunakan media internet merupakan masalah yang menarik, sebab semua transaksi jual beli melalui internet ini dilakukan tanpa ada tatap muka antara para pihaknya, sehingga yang terjadi diantara para pihak pun dilakukan secara elektronik baik melalui e-mail atau cara lainnya, oleh karena itu tidak ada berkas perjanjian seperti pada transaksi jual beli konvensional, tentu saja dapat menimbulkan berbagai akibat hukum dengan segala konsekuensinya, antara lain apabila muncul suatu perbuatan yang melawan hukum dari salah satu pihak, akan menyulitkan pihak yang dirugikan untuk menuntut segala kerugian yang timbul dan disebabkan perbuatan melawan hukum Kenyataan seperti ini merupakan hal-hal yang harus mendapat perhatian dan pemikiran untuk dicarikan solusinya, karena transaksi jual beli yang dilakukan melalui internet tidak mungkin terhenti, sementara perlindungan dan kepastian hukum bagi para pengguna internet tersebut tidak mencukupi, dengan demikian harus diupayakan untuk tetap mencapai keseimbangan hukum dalam kondisi tersebut, sebab electronic commerce merupakan suatu konsep perdagangan yang baru yang sampai saat ini masih perlu dikaji oleh para ahli di Indonesia. Hal lain yang mendorong dalam meneliti permasalahan ini, dikarenakan perjanjian jual beli merupakan salah satu komponen penting dalam dunia perdagangan yang sangat berperan dalam menunjang pembangunan nasional. Berdasarkan uraian di atas hal menarik untuk dilakukan pengkajian adalah yang berkaitan dengan relevansi peraturan perundang - undangan yang sudah ada dengan kebutuhan akan peraturan dalam transaksi jual beli melalui media internet. maka penulis tertarik untuk mengangkat suatu judul penelitian yaitu "Perlindungan Hukum Kepentingan Para Pihak Dalam Transaksi Online"

Tujuan secara umum dari penulisan ini yakni untuk mengembangkan teori hukum pada aspek jual beli secara online di hukum perdata khususnya di bidang perjanjian. Tujuan khususnya adalah untuk mengetahui serta memahami mekanisme dan pengaturan transaksi melalui media online dan untuk menemukan, menganalisis secara mendalam perlindungan terhadap kepentingan para pihak dalam transaksi online. sesuai dengan rumusan masalah tujuan penelitian ini yaitu untuk mengetahui kedudukan jabatan Notaris ketika terjadi penahanan sementara dalam proses pengadilan dan untuk mengetahui bentuk pemulihan hak Notaris pasca terjadinya putusan pengadilan. 


\section{Metode Penelitian}

Suprapto menafsirkan metode sebagai sebuah instrument yang digunakan sebagai alat pengumpulan data. ${ }^{6}$ Sehubunngan dengan itu, penelitian ini menggunakan metode normatif (doctrinal research) yang menurut A. Muktie Fajar dan Yulianto Ahmad adalah bentuk penelitian yang menitikberatkan pada sistematika, kondisi serta sinkronisasi sebuah produk hukum. ${ }^{7}$ Dalam penulisan ini sumber bahan hukum yang digunakan ialah bahan hukum primer berupa Kitab Undang-Undang Hukum Perdata, Undang-Undang No. 8 Tahun 1999 tentang Perlindungan Konsumen dan UU No. 19 Tahun 2016 tentang perubahan atas UU Nomor 11 Tahun 2008 tentang Informasi dan Transaksi Elektronik Bahan Hukum Sekunder, yaitu materi yang memberikan penjelasan mengenai bahan hukum primer, diantaranya literaturliteratur, buku- buku, dan bermacam penulisan ilmiah lainnya sedangkan bahan hukum tersier, yakni bahan-bahan yang memberikan patokan maupun penjelasan terhadap bahan hukum primer dan sekunder, yang terdiri dari artikel, kamus hukum, dan internet.

Pendeketan yang digunakan pada penulisan tesis ini yakni pendekatan perundangundangan dan pendekatan konsep. Arti pendekatan perundang-undangan yang dimaksud yaitu dengan mengamati peraturan perundang-undangan yang sah sedangkan Pendekatan konsep dimaksudkan pendekatan dengan melihat pada pendapat ahli tentang objek yang diteliti. ${ }^{8}$

Dalam penelitian ini, teknik dalam menganalisa bahan hukum yang digunakan berdasarkan dengan sifat penelitian hukum normatif. Oleh sebab itu analisa bahan hukum dilakukan dengan teknik deskripsi, interpretasi dan argumentasi. Hal yang pertama akan dilakukan interpretasi otentik yakni dengan menggunakan pengertian yang ditegaskan di dalam peraturan perundang-undangan. Apabila hal ini tidak cukup, maka akan dilakukan interpretasi gramatikal dengan cara menemukan arti dan konsep yang terdapat didalam kamus. Selain itu, dilakukan juga interpretasi sistematis, yakni dengan memilih hubungan antara satu pasal dengan pasal yang lain, yang terdapat didalam peraturan perundang- undangan yang berlaku dan terkait dengan transaksi melalui media online.

\section{Hasil dan Pembahasan}

\subsection{Mekanisme Dan Pengaturan Transaksi Dengan Menggunakan Media Online}

E-commerce belum memiliki istilah yang uniform dalam bahasa Indonesia sebab merupakan sebuah konotasi yang diambil dari bahasa asing. Banyak pihak cenderung menyamakan makna dari e-commerce dengan bisnis elektronik, kontrak dagang elektronik, transaksi perniagaan elektronik dan transaksi perdagangan melalui

\footnotetext{
${ }^{6}$ Suprapto, 2013, Metodologi Penelitian Ilmu Pendidikan dan Ilmu-Ilmu PengetahuanSosial (Penelitian Kuantitatif dan Kualitatif Dilengkapi dengan Teknik Pengolahan Data dan Tabel Statistik), Bogor: CAPS

${ }^{7}$ Muktie Fajar dan Yulianto Ahmad, 2009, Dualisme Penelitian Hukum Normatif dan Empiris, Yogyakarta: Pustaka Pelajar

8 H. Bahdin Nur Tanjung dan H. Ardinal, 2009, Pedoman Penulisan Karya Ilmiah, Kencana, Medan, hlm.62.
} 
elektronik. ${ }^{9}$ Transaksi jual beli itu merupakan bagian kecil dari seluruh kegiatan electronic commerce di dunia ini, sebab electronic commerce itu lebih menunjuk pada sistem niaga dengan menggunakan jaringan komunikasi data pada tingkat lokal, regional dan global sedangkan transaksi jual beli dengan internet adalah salah satu cara mengaplikasikan electronic commerce sehingga merupakan bagian dari electronic commerce. ${ }^{10}$ Di dalam transaksi jual-beli barang dan jasa setidak-tidaknya terdapat dua pihak yang saling berhubungan, yaitu: pertama, pihak penyedia barang atau penyelenggara jasa, kedua, pihak pemakai/pengguna barang atau jasa itu. ${ }^{11}$

Jadi dapat disimpulkan Electronic commerce adalah melakukan transaksi eletronik dengan melalui media suatu jaringan (electronic transaction over network), jadi "semua jenis transaksi atau tukar menukar jasa melalui suatu jaringan yang dibentuk bersama dapat digolongkan ke dalam suatu electronic commerce". Pada transaksi jual beli dengan cara elektronik, yang di dalamnya terkait para pihak yang melaksanakan hubungan hukum, yang dilaksanakan berdasarkan suatu perjanjian secara elektronik yang diatur dalam Pasal 1 butir 17 Undang-Undang Informasi dan Transaksi Elektronik yang disebut sebagai kontrak elektronik yaitu perjanjian yang termuat di dalam dokumen elektronik atau media elektronik lainnya. Dengan adanya kemudahan teknologi internet, maka menghasilkan transaksi yang dapat dilaksanakan baik dalam lingkup publik ataupun privat.

Dapat dibayangkan, antara komputer yang satu dengan komputer lainnya Indonesia, lebih mudah dibayangkan jumlah adanya relasi yang terjadi dan jumlah orang didunia ini yang saling berinteraksi, hal ini yang dinamakan the virtual world atau cyber world/ space dan sekumpulan orang-orang yang berinteraksi melalui jaringan komunikasi data yang tersebar di seluruh dunia disebut "cyber society atau Global Information Society (GIS)"karena sebenarnya masyarakatnya tidak mengenal batas ruang dan waktu. Menurut teori hukum, bahwa keberadaan masyarakat akan tetap disertai dengan hukum "Ubi Societas Ibi Ius"

Di dalam transaksi jual-beli barang dan jasa setidak-tidaknya terdapat dua pihak yang saling berhubungan, yaitu: pertama, pihak penyedia barang atau penyelenggara jasa, kedua, pihak pemakai/pengguna barang atau jasa itu. ${ }^{12}$ Selain itu, dalam transaksi jual beli melalui media internet juga melibatkan provider sebagai penyedia jasa layanan jaringan internet dan bank sebagai sarana pembayaran. Pelaku usaha dengan menawarkan barang atau jasanya secara elektronik harus menyediakan informasi mengenai syarat-syarat perjanjian, produsen dan produk dengan lengkap dan benar. Pada Pasal 17 Ayat (1) Undang-Undang Informasi dan Transaksi Elektronik menyebutkan bahwa "penyelenggaraan transaksi elektronik dapat dilakukan dalam lingkup publik ataupun privat". Dalam Ayat (2) menyebutkan "para pihak yang melakukan transaksi elektronik sebagaimana dimaksud pada ayat (1) wajib beritikad baik dalam melakukan interaksi dan/atau pertukaran informasi elektronik dan/atau dokumen elektronik selama transaksi berlangsung." Menurut Pasal 19 Undang-

\footnotetext{
${ }^{9}$ Ridyanti Dorotea Tobing.,Op.cit,hlm.209

${ }^{10}$ Joko Yuliantoro et.a; September 1998,Electronic commerce: Benarkan meningkatkan efektifitas dan efesiensi perusahaan and ? Info Komputer, Vol. XII/No. 9 hlm. 52

11 Firman Tumantara, 2016, Hukum Perlindungan Konsumen (Filosofi Perlindungan Konsumen dalam Persfektif Politik Hukum Negara Kesejahteraan), Setara Press, Malang, hlm.4

12 Firman Tumantara, Op.cit, hlm.4.
} 
Undang Informasi dan Transaksi Elektronik menyebutkan bahwa "para pihak yang melakukan transaksi elektronik harus menggunakan sistem elektronik yang disepakati". Jadi sebelum melaksanakan transaksi elektronik, maka kedua belah pihak menyetujui sistem elektronik yang hendak dipergunakan saat melaksanakan transaksi. Suatu transaksi elektronik berlangsung pada saat penawaran transaksi yang telah diantar pengirim serta diterima atau disetujui oleh penerima sebagai halnya diatur pada Pasal 20 ayat (1) Undang-Undang Informasi dan Transaksi Elektronik. Berdasarkan hal ini transaksi elektronik akan baru berlangsung apabila adanya suatu penawaran yang diberikan kepada penerima dan adanya kesepakatan untuk menerima penawaran tersebut secara elektronik. Pasal 20 ayat (2) Undang-Undang Informasi dan Transaksi Elektronik disebutkan "Persetujuan atas penawaran transaksi elektronik harus dilakukan dengan pernyataan penerimaan secara elektronik". Pada Pasal 21 ayat (2) angka 1 menyebutkan bahwa "apabila transaksi dilakukan sendiri, maka orang yang melakukan transaksi yang menanggung akibat hukumnya".

Jonathan Surwono mendeskripsikan tindakan electronic commerce sebagai sebuah kerangka ecubesystem yang terdiri dari template, dekostumisasi bahasa, layanan web prima, serta layanan katalog. Konsep electronic-commerce menempatkan seorang pelaku usaha (merchant) sebagai provider produk menggunakan merchant account. Sedangkan pembeli cenderung dibahasakan dengan istilah card holder oleh karena kepemilikan atas sebuah kartu kredit (credit card) yang kelak menentukan sejauh mana kesuksesan bertransaksi. ${ }^{13}$

Tindakan electronic commerce dalam dunia perniagaan tidak sepenuhnya aman sebab terdapat beberapa konsekuensi yang harus dihadapi oleh seorang pelaku usaha. Sebelum berbicara lebih jauh lagi, penting untuk memahami mekanisme dari electronic commerce itu sendiri. Hal ini diawali dengan (1) Kontrak dagang; (2) Dilaksanakan melalui media elektronik; (3) bersifat paper less; (4) tidak membutuhkan kehadiran fisik; (5) terjalin dalam jaringan publik, (6) sistem terbuka, (7) melampaui batas yurisdiksi; (8) bernilai ekonomis. ${ }^{14}$ melalui beberapa tahapan yaitu :

1. Calon pelanggan / pembeli pertama-tama harus memasuki website Setelah masuk ke website tersebut maka ia akan dihadapkan pada 3 buah modul, yaitu : modul keanggotaan, modul katalog barang dan modul order.

a. Modul Keanggotaan berisi tentang pelanggan/customer jasa pengirim, termasuk petugas Jasa Pengirim. Selain berisi karakteristik pelanggan, dari modul ini juga diperoleh data tentang : waktu penggunaan, dan aktivitas yang pernah dilakukan;

b. Modul Katalog berisi tentang produk dari Jasa Pengirim barang yang berisi tentang data-data lengkap mengenai jenis barang, harga barang dan jumlah yang tersedia di tempat penyimpanan barang;

c. Modul Order berisi tentang pesanan-pesanan barang yang dilakukan oleh anggota yang dilakukan secara online melalui icon order otomatis, dengan pengisian formulir pesanan barang secara online. Order dilakukan dengan pemilihan pesanan barang, setelah dikonfirmasi, secara otomatis order langsung disampaikan kepada Pihak Jasa Pengirim barang dan kurir.

13 Jonathan Surwono dan Tutty Martadiredja, 2008, Teori E-Commerce dan Kunci Sukses Perdagangan di Internet, Bandung: Gava Media,hlm. 3.

${ }^{14}$ Rudyanti Dorothea Tobing.,Op.cit,hlm. .211. 
2. Untuk mengadakan suatu transaksi maka calon pelanggan harus pertama-tama mengisi modul keanggotaan, selanjutnya melihat modul katalog untuk memilih dan memesan barang yang dikehendakinya dengan modul order.

3. Selanjutnya pihak jasa pengirim mengolah modul order dan mengkonfirmasikan cara pelunasan yang akan digunakan oleh pembeli kepada Bank, dengan cara pembayaran menggunakan kartu kredit ataupun kartu debit, dan kepada pihak kantor pos apabila cara pembayaran yang dilakukan adalah menggunakan weselpos elektronik;

4. Lembaga keuangan yang terkait akan melakukan sistem otorisasi dan konfirmasi terhadap berbagai hal, seperti: ketersediaan dana, legalitas pembayaran, validitas informasi, dan lain sebagainya. Apabila mengikutsertakan lebih dari satu bank atau lembaga keuangan, maka sistem otorisasi dan konfirmasi akan dilaksanakan secara elektronik dengan menggunakan jaringan internet antar bank atau lembaga keuangan yang ada, secara otomatis hasilnya akan diberitahukan kepada pembeli melalui situs perusahaan, apabila berhasil, maka pembeli dapat melakukan tahapan selanjutnya dan apabila otorisasi dan konfirmasi tidak berhasil maka akan diinformasikan melalui situs yang sama. Berbagai upaya yang biasanya dilakukan oleh perusahaan ataupun bank untuk menerangkan kepada pembeli bahwa proses pembayaran telah dilakukan secara benar dan berhasil, seperti:

a. Pemberitahuan melalui email mengenai status transaksi jual beli produk atau jasa yang telah dijalankan;

b. Pemberian dokumen elektronik yang dikirim melalui email atau situs terkait yang memuat "berita acara" jual beli mengenai tanda pembayaran yang berisi jenis produk atau jasa yang dibeli beserta spesifikasi sistem pembayaran yang telah dilakukan, selanjutnya pengiriman tanda pembayaran (kwitansi) akan dilakukan saat pengantaran barang ke konsumen melalui jasa kurir

5. Pihak bank akan mendebit sejumlah uang dari rekening pihak pembeli untuk transaksi yang dilakukan apabila menggunakan wesel pos elektronik, cara pembayaran sedikit berbeda, yaitu pembeli sebelum mengisi modul order maka terlebih dahulu harus mengirimkan sejumlah uang sebesar harga barang yang di pesan kepada pihak produsen. Setelah itu akan mendapatkan resi yang berisi kode pengiriman, kode tersebut yang nantinya harus diisi dalam modul order."

6. Setelah mendapatkan konfirmasi, maka pihak Jasa Pengirim akan menginstruksikan kepada pihak kurir untuk mengirimkan barang pesanan sesuai dengan modul order yang diberikan oleh pihak pembeli ke alamat pembeli tepat pada waktunya sesuai dengan isi perjanjian;

Pengaturan hukum berupa peraturan perundang-undangan tentang cyber dan elecronic commerce seyogiyanya mencakup perangkat hukum yang berkaitan, sehingga menjadi satu subsistem di dalam sistem hukum nasional. Oleh karena itu, perlu dilakukan perluasan makna dari KUH perdata, Undang-Undang hak cipta, Undang-Undang perlindungan konsumen, Undang-undang Informasi Teknologi. Elektronik dan Undang-Undang merek terkait dengan hal tersebut. Masalah-masalah legal di internet yang belum terjangkau oleh hukum secara jelas antara lain, kontrak online, Privasi, Electronic Commerce, pembayaran elektronik, tanggung jawab pembuat homepage, email, dan chat. Dalam hal kontrak dilakukan di cyberspace, peraturan tidak memiliki perbedaan. Namun, bagaimanapun terdapat keadaan di cyberspace yang sama sekali 
baru dan tidak ada suatu ketentuan pun yang berlaku sehingga menyebabkan ketidakpastian dan resiko.

\subsection{Perlindungan Terhadap Kepentingan Para Pihak Dalam Transaksi Online}

Ada lima unsur di dalam electronic commerce yang saling terikat yakni Subjek Hukum, transaksi dengan teknologi informasi, perjanjian, alat bukti elektronik dan tanggung jawab. Subyek hukum yang dimaksud ialah merchant dan customer, yang melaksanakan transaksi berdagang menggunakan teknologi internet sehingga menimbulkan adanya suatu perjanjian. Perlindungan hukum dalam hal perjanjian, alat bukti elektronik, dan tanggung jawab para pihak berdasarkan penelitian penulis :

1. Perlindungan hukum di dalam perjanjian Electronic Commerce.

Didalam perjanjian tersebut tentu ada dokumen elektronik, yang mampu digunakan sebagai alat bukti elektronik dalam hal memungkiri adanya penyalahgunaan oleh pihak yang tidak bertanggung jawab yang bersifat kejahatan perdagangan secara elektronik. Berdasarkan hal itu maka perlu adanya suatu perlindungan hukum, yang tujuannya melindungi subyek hukum saat melaksanakan transaksi perdagangan dengan menggunakan media internet.

2. Ketentuan itu juga dipergunakan sebagai perlindungan hukum untuk para pihak diantaranya:

- Perlindungan hukum terhadap merchant menekankan pada pembayaran, merchant mengwajibkan customer untuk melaksanakan pembayaran secara lunas, selanjutnya dilakukan konfirmasi pembayaran, dan tahap berikutnya adalah melakukan pengiriman barang-barang yang telah dibeli.

- Perlindungan hukum untuk customer berada pada garansi yaitu pengembalian atau penukaran barang apabila barang yang diterima tidak seperti apa yang dibeli.

- Privacy, pemerintah merumuskan beberapa aturan dalam dunia perdagangan yakni melalui Pasal 9 UU ITE yang mewajibkan seseorang untuk memaparkan identitasnya secara jelas sebagai pelaku usaha, Pasal 10 ayat (1) UU ITE, bahwa pelaku usaha harus sah dengan bukti sertifikasi lembaga keandalan serta pelaku usaha harus mempertanggungjawabkan segala kerugian akibat transaksi sesuai rumusan Pasal 12 ayat (3) UU ITE. Identitas bagi pengguna media elektronik wajib mendapat perlindungan hukum. ${ }^{15}$ Pemberian informasi identitas wajib disertakan persetujuan oleh pemilik identitas, hal ini termasuk bentuk perlindungan hukum terhadap para pihak yang melaksanakan transaksi e-commerce, yang telah diatur pada ketentuan Pasal 25 Undang-Undang Informasi dan Transaksi Elektronik "Informasi elektronik dan/atau dokumen elektronik.

Dengan diberlakukan Undang-Undang Nomor 8 Tahun 1999 mengenai Perlindungan Konsumen, masalah mengenai perlindungan konsumen akan menjadi hal yang terpenting, dengan hadirnya keberadaan undang-undang ini tidak semata memberikan penawaran kedudukan yang kuat kepada konsumen yaitu dengan melindungi hak-haknya, tetapi juga untuk mengwujudkan proses ketentuan yang

15 Shohib Muslim dan Farida Akbarina, 2016, Kajian Tentang Aspek Hukum Bisnis dan Perlindungan Konsumen Dalam Transaksi E-Commerce, Journal Administrasi dan Bisnis, Vol. 10, No. 1, Malang, Politeknik Negeri Malang 
lebih fair kepada semua pihak. Ketentuan hukum perlindungan konsumen tidak bertujuan untuk menjatuhkan pelaku usaha, melainkan malah sebaliknya perlindungan konsumen mampu memajukan keadaan usaha yang kondusif serta melahirkan perusahaan yang unggul saat menuju persaingan dengan pengadaan barang dan jasa yang bermutu. Dalam hubungannya dengan kemajuan teknologi komunikasi dan informasi, dapat memperdagangkan kepada konsumen yaitu barang dan jasa dengan melintasi batasan wilayah, maka perlindungan konsumen akan tetap sebagai hal terpenting yang harus mendapat perhatian.

Kedudukan pihak konsumen dan pelaku usaha harus mendapatkan perlindungan hukum. Pada umumnya, posisi konsumen lebih lemah dibandingkan dengan pelaku usaha, hal ini hubungannya dengan nilai kesadaran atas haknya, potensi financial, dan posisi tawar (bargaining position) yang kurang. Ketentuan hukum harus tidak membawa ketimpangan, tetapi ketentuan hukum harus menempatkan kedudukan yang adil, dimana hubungan konsumen dengan pelaku usaha berada pada sikap yang saling menghendaki dan memiliki keterkaitan antar pihak. Hendaknya saat bertransaksi jual beli dengan menggunakan internet, sikap teliti dan hati-hati harus dimiliki konsumen atas penawaran yang diberikan pelaku usaha. Ketika memesan barang, konsumen harus memastikan dahulu merchant mencantumkan identitas jelas dan nomor telepon yang dapat dihubungi, maka terlebih dahulu melakukan tindakan komunikasi aktif dengan menanyakan secara terus menerus mengenai produk yang akan dibeli terhadap pelaku usaha, mampu untuk menekan dampak kerugian bagi pembeli.

Menurut Shidarta dalam bukunya "Hukum Perlindungan Konsumen" secara umum dikenal ada 4(empat) hak dasar konsumen, yaitu :

1. Hak untuk mendapat keamanan (the right to safety).

2. Hak untuk mendapat informasi (the right to be informed).

3. Hak untuk memilih (the right to choose).

4. Hak untuk didengar (the right to be heard).

Empat hak dasar ini diakui secara internasional. ${ }^{16}$ Berdasarkan analisis, pada transaksi e-commerce hak-hak konsumen sangat riskan sekali untuk dilanggar, dalam hal ini konsumen tidak mendapatkan hak-haknya secara penuh dalam transaksi e-commerce. Berdasarkan Undang-Undang Informasi Dan Transaksi Elektronik dan Peraturan Pemerintah Penyelenggara Sistem Transaksi Elektronik mengenai transaksi jual beli, walaupun dilakukan melalui online, akan tetap dipastikan sebagai transaksi elektronik yang dapat dipertanggungjawabkan. Pada Pasal 48 ayat (3) Peraturan Pemerintah Penyelenggara Sistem Transaksi Elektronik menyebutkan mengenai "kontrak elektronik yang setidaknya harus memuat hal-hal diantaranya identitas para pihak, objek dan khusus termuat ketentuan transaksi elektronik harga dan biaya, mekanisme dalam hal adanya pembatalan oleh para pihak, ketentuan dalam hal pemberian hak kepada pihak yang dirugikan, untuk dapat mengembalikan barang dan/atau mensyaratkan penggantian produk apabila adanya cacat tersembunyi dan pilihan hukum dalam menyelesaikan Transaksi Elektronik".

${ }^{16}$ Celina Tri, 2014, Hukum Perlindungan Konsumen, cet. IV, Sinar Grafika, Jakarta, hlm.31. 
Berdasarkan hal tersebut, saat transaksi elektronik berjalan agar menggunakan instrumen perundang-undangan tentang Informasi Transaksi Elektronik dan/atau Peraturan Pemerintah Penyelenggara Sistem Transaksi Elektronik sebagai aturan hukum untuk penyelesaian masalah. Mengenai perlindungan konsumen, pada Pasal 49 ayat (1) Peraturan Pemerintah Penyelenggara Sistem Transaksi Elektronik menyebutkan "Pelaku usaha yang menawarkan produk melalui sistem elektronik wajib menyediakan informasi yang lengkap dan benar berkaitan dengan syarat kontrak, produsen, dan produk yang ditawarkan. Pada ayat berikutnya lebih ditegaskan lagi bahwa pelaku usaha wajib memberikan kejelasan informasi tentang penawaran kontrak atau iklan." Apabila produk yang dipesan konsumen tidak seperti apa diperjanjikan, maka dalam Pasal 49 ayat (3) Peraturan Pemerintah Penyelenggara Sistem Transaksi Elektronik mengarahkan lebih spesifik mengenai masalah diatas, yaitu "Pelaku Usaha wajib memberikan batas waktu kepada konsumen untuk mengembalikan barang yang dikirim apabila tidak sesuai dengan perjanjian atau terdapat cacat tersembunyi". Pada bukunya mengenai Hukum Perjanjian R. Subekti berpendapat, wanprestasi ialah kelalaian atau kealpaan yang berwujud 4 jenis keadaan diantaranya:

a. Tidak menjalankan sesuai dengan kesanggupannya;

b. Melaksanakan suatu perjanjian, tetapi menyimpang dengan perjanjian yang dibuat

c. Suatu perjanjian dilaksanakan namun terlambat;

d. Melaksanakan suatu yang tidak diperbolehkan untuk dilakukan berdasarkan perjanjian ${ }^{17}$

Apabila salah satunya hal diatas dilakukan, maka sesuai Hukum Perdata penjual online dapat digugat dengan dasar adanya wanprestasi (misalnya, saat menerima barang tidak sema seperti spesifikasi barang yang ditampilkan pada beranda suatu laman online). ${ }^{18}$

\section{Kesimpulan}

Mekanisme perjanjian jual beli dengan menggunakan online melalui perantara atau pelaku usaha dimana calon pembeli, pertama harus memasuki website pelaku usaha dan kemudian telah diterima menjadi anggota perantara atau pelaku usaha, langkah selanjutnya diperkenankan melihat katalog barang serta kemudian melakukan transaksi.

Pelinungan hukum terhadap merchant menekankan pada pembayaran, merchant mewajibkan customer untuk melaksanakan pembayaran secara lunas, selanjutnya dilakukan konfirmasi pembayaran, dan tahap berikutnya adalah melakukan pengiriman barang-barang yang telah dibeli, Perlindungan hukum untuk customer berada pada garansi yaitu pengembalian atau penukaran barang apabila barang yang diterima tidak seperti apa yang dibeli dan Privacy. Perlindungan hukum dalam traansaksi online tidak hanya diberikan oleh satu aspek hukum saja melainkan oleh suatu sistem hukum yang mampu memberikan perlindungan yang simultan dan

17 Subekti, R, 2000., Hukum Perjanjian, Cetakan ke-VIII, PT Intermasa, Jakarta

18 http://www.hukumonline.com/klinik/detail/1 t50bf69280b1ee/perlindungankonsumendala-e-commerce, diakses pada tanggal 20 Mei 2019 
komprehensif. Perlindungan Hukum Bagi Para Pihak Dalam Electronic Commerce mencakup 2 (dua) sisi yaitu dalam Perjanjian dan diluar Perjanjian. Perlindungan didalam perjanjian Perlindungan hukum didalam perjanjian Electronic Commerce, dokumen tersebut dibuat oleh pihak merchant yang berisi aturan dan kondisi yang harus dipatuhi oleh customer tetapi isinya tidak memberatkan customer.

Harapan disusun buku pedoman yang mengatur tentang transaksi perdagangan dengan menggunakan media internet bagi para pelaku transaksi tersebut dan untuk lebih memberikan perlindungan hukum sebaiknya pihak pelaku usaha mencantumkan terms and conditions dalam modul yang khusus guna memberikan kejelasan perihal hak dan kewajiban para pihak dan Diperlukan peran aktif pemerintah untuk segera melihat perkembagangan didalam pengaturan electronic commerce khususnya masalah kontrak, agar dibuat aturan agar setiap kontrak yang ditawarkan didalam situs internet haruslah terlebih dahulu diundangkan didalam Lembaran Negara atau Lembaran Daerah.

\section{Daftar Pustaka}

Buku

Berkatullah, Abdul Halim. 2005. Bisnis E-Commerce (Studi sistem keamanan dan Hukum di Indonesia). Yogyakarta: Pustaka Pelajar.

Fajar, A. Muktie dan Yulianto Ahmad. 2009. Dualisme PenelitianHukum Normatif dan Empiris. Yogyakarta: Pustaka Pelajar

R, Subekti, 2000., Hukum Perjanjian. Cetakan ke-VIII, PT Intermasa, Jakarta

Sjahputra, Iman. 2010. Perlindungan Konsumen dalam Transaksi Elektronik. Bandung : PT. Alumni

Suprapto. 2013. Metodologi Penelitian Ilmu Pendidikan dan Ilmu-Ilmu Pengetahuan Sosial (Penelitian Kuantitatif dan Kualitatif Dilengkapi dengan Teknik Pengolahan Data dan Tabel Statistik). Bogor: CAPS

Surwono, Jonathan dan Tutty Martadiredja. 2008. Teori ECommercedan Kunci Sukses Perdagangan di Internet.Bandung: Gava Media.

Tanjung, H. Bahdin Nur dan H. Ardinal. 2005. Pedoman Penulisan Karya Ilmiah (Proposal, Skripsi dan Tesis). Medan: Kencana

Tobing, Ridyanti Dorotea. 2015. Aspek-Aspek Hukum Bisnis (Pengertian, Asas, Teori dan Praktik. Palangka Raya: LaksBang Justitia.

Tri, Celina. 2014. Hukum Perlindungan Konsumen. cet. IV, Sinar Grafika. Jakarta

Tumantara, Firman. 2016. Hukum Perlindungan Konsumen (Filosofi Perlindungan Konsumen dalam Persfektif Politik Hukum Negara Kesejahteraan). Setara Press. Malang

\section{Jurnal}

Megawati, Ni Ketut Dewi. 2016. Perspektif Undang-Undang No. 1 Tahun 2011 Tentang Perumahan dan Kawasan Pemukiman Terhadap Perlindungan Hak Konsumen Dalam Jual Beli Perumahan. Journal Magister Hukum Udayana. Vol. 5. No. 1 Denpasar. Program Studi Magister Ilmu Hukum Pasca Sarjana Universitas udayanaDeny Rahadja, Jan-Feb1999, Siapakah kita untuk E-commerccce, Info Komputer, Vol. I/No.2 
Shohib Muslim dan Farida Akbarina, 2016, Kajian Tentang Aspek Hukum Bisnis dan Perlindungan Konsumen Dalam Transaksi E-Commerce, Journal Administrasi dan Bisnis, Vol. 10, No. 1, Malang, Politeknik Negeri Malang

Tetanoe, Bernada, 2017, Upaya Perlindungan Hukum Pada Konsumen Dalam Transaksi E-Commerce Untuk Mendukung Pertumbuhan Ekonomi Digital Di Indonesia Journal Jurnal Hukum dan Peradilan, Vol. 6 Nomor 1, Fakultas Hukum Universitas Pelita

Joko Yuliantoro et.a; September 1998,Electronic commerce: Benarkan meningkatkan efektifitas dan efesiensi perusahaan and? Info Komputer, Vol. XII/No. 9 hal. 52

\section{Website}

http://www.hukumonline.com/klinik/detail/1 t50bf69280blee/perlindungankonsumendala-e-commerce diakses tanggal 20 Mei2019

\section{Peraturan Perundang-Undangan}

Kitab Undang-Undang Hukum Perdata (Burgerlijk Wetboek).Diterjemahkan oleh Subekti dan R. Tjitrosudibio. Jakarta: Pradnya Paramita, 2008.

Undang-Undang No. 8 Tahun 1999 tentang Perlindungan Konsumen, Dicatatkan dalam Lembar Negara Republik Indonesia Tahun 1999 No. 43 dan Tambahan Lembar Negara Republik Indonesia No. 3821.

Indonesia, Peraturan Pemerintah Republik Indonesia Nomor 82 Tahun 2012 tentang Penyelenggara Sistem dan Transaksi Elektronik (Lembaran Negara Republik Indonesia Tahun 2012 Nomor 189)

Undang-Undang No. 19 Tahun 2016 tentang Perubahan Terhadap UndangUndang No. 11 Tahun 2008 tentang Informasi dan Transaksi Elektronik, Dicatatkan dalam Lembar Negara Republik Indonesia Tahun 2016 No. 251 dan Tambahan Lembar Negara Republik Indonesia No. 5952 